Relations industrielles

Industrial Relations

\title{
Rupp, Kalman and David C. Stapleton (editors), Growth in Disability Benefits: Explanations and Policy Implications
}

\section{Silvana Pozzebon}

Volume 54, numéro 3, 1999

URI : https://id.erudit.org/iderudit/051262ar

DOI : https://doi.org/10.7202/051262ar

Aller au sommaire du numéro

Éditeur(s)

Département des relations industrielles de l'Université Laval

ISSN

0034-379X (imprimé)

1703-8138 (numérique)

Découvrir la revue

Citer ce compte rendu

Pozzebon, S. (1999). Compte rendu de [Rupp, Kalman and David C. Stapleton (editors), Growth in Disability Benefits: Explanations and Policy Implications]. Relations industrielles / Industrial Relations, 54(3), 624-626.

https://doi.org/10.7202/051262ar

Tous droits réservés @ C Département des relations industrielles de l'Universite Laval, 1999
Ce document est protégé par la loi sur le droit d'auteur. L’utilisation des services d'Érudit (y compris la reproduction) est assujettie à sa politique d'utilisation que vous pouvez consulter en ligne.

https://apropos.erudit.org/fr/usagers/politique-dutilisation/ 
reflective (i.e., description and explanation of the challenges) than managerial or action oriented (i.e., how to manage or to deal with these challenges). As with almost all conference proceedings, there is a high degree of variance in the relevance and the quality of the contributions. Furthermore, as it is not a deep or exhaustive investigation of this subject, but rather set of specific essays on a variety of topics, readers will be more aware of the various challenges with respect to work and family but will not be provided with answers as to how to deal with each of them.

In summary, it is a typical collection expressing various sociological perspec- tives and survey results on a variety of topics related to the new world of work and family life in North America and from a variety of actor perspectives (employees, government, employers, specific identity groups based on race, sex, etc.). The table of contents is therefore essential as readers will choose some articles rather than others based upon their own interests (as well as the continuing relevance of the data).

SYLVIE ST-ONGE École des Hautes Études Commerciales, Montréal GILLES GUÉRIN Université de Montréal

\section{Growth in Disability Benefits: Explanations and Policy Implications \\ edited by Kalman RuPP and David C. STAPLETON, Kalamazoo, Mich.: W.E. Upjohn Institute for Employment Research, 1998, 435 p., ISBN 0880991887 (cloth: alk. paper) and 0880991879 (pbk.: alk. paper).}

This volume features a collection of research and discussion papers from disability policy experts, as well as disability program administrators, presented at a 1995 conference in Washington, D.C. The purpose of the text is to diffuse research findings that seek to explain the unanticipated expansion of two disability program rolls administered by the U.S. federal government's Social Security Administration (SSA): Disability Insurance (DI) and Supplemental Security Income (SSI). A second objective of the book is to understand the policy implications of the growth of these disability programs. Research reported in the volume was carried out during the $1992-95$ period, subsequent to a mandate from Congress to investigate the near-insolvency of federal disability program funds in 1992.

For the benefit of readers less familiar with the U.S., I will briefly review the role of the Social Security Administration. The general mission of this organization is to administer the government-sponsored retirement income program for all Americans. DI was originally conceived as a bridge program for workers who became disabled during the course of their work life, but were too young to retire and were not eligible to receive benefits under other income replacement programs. On the other hand, SSI is means-tested, providing benefits to poor disabled individuals with insufficient work histories to qualify for DI. Low income DI recipients may receive SSI payments concurrently with DI, with many $\mathrm{DI}$ applicants qualifying for SSI during the five month waiting period before they are eligible for DI benefits.

Both DI and SSI have historically accounted for a relatively small portion of the SSA's activities and expenditures. Recent economic and population developments, as well as administrative factors, have increased the importance of both DI and SSI spending, especially since beneficiaries of these programs are also eligible for health care benefits. With the exception of the elderly and the indigenous, most Americans receive medical insurance coverage through their employer. It should be noted that rapidly 
rising health care costs continue to plague the U.S.

The book is divided into three major sections. The first part of the volume contains four chapters summarizing results of empirical analyses conducted on national level data. Chapter 2 (Stapleton et al.), describes econometric research results of what could be qualified as the most comprehensive attempt in the volume to identify factors associated with disability program growth. These factors include population changes, the effect of the business cycle, the interaction of federal disability programs with other public assistance programs (notably, the effect of cuts in state and local welfare programs), and the expansion in the supply of benefits (for example, loosening of eligibility criteria). Stapleton et al. conclude that the latter three factors are major causes of the expansion of disability rolls. Interestingly, the strong performance of the American economy since the recession of the early 1990s has partly abated the growth of disability programs, lending further credence to findings in this chapter that highlight the importance of the business cycle.

The remaining chapters ( 3 to 5 ) in the first section of the volume delve into some of the particular issues raised in Chapter 2. In Chapter 3, Yelowitz attempts to determine whether the availability of public health insurance as a supplemental benefit to $\mathrm{SSI}$ recipients explains caseload growth. Though the author concludes that the evidence suggests such a relationship, results are rather tentative. In the subsequent chapter, Rupp and Scott's study indicates that the shift towards younger entrants to disability programs, especially the recent influx of a large number of children to the SSI rolls, is expected to increase benefit duration. Finally, Chapter 5 (Daly) showcases findings from a first empirical attempt to examine the characteristics of individuals who subsequently become disability program recipients. But, as Daly points out, data limitations hamper efforts in this direction.

The second part of the volume presents findings from qualitative research conducted at the state or local level. The perceptions of SSA field officers gathered from survey data is documented in Chapter 6 , while Chapter 7 describes how the elimination of the state of Michigan's welfare program spurred growth in SSI applications. Chapter 8 provide insights based on case studies of the experience of five U.S. states, including Michigan.

Overall, the evidence presented in the second part of the book, which is based on qualitative data, corroborate findings from the empirical analyses described in the first section. These results emphasize the importance of the business cycle, of state efforts to shift the burden of welfare to the federal government and of the expansion of the supply of benefits in explaining disability roll growth. But the qualitative data in this section provides details and insights into the functioning of the disability programs not captured in the first part of the book, resulting in a much richer and more complete portrait of reasons for the expansion of federal disability programs. Particularly striking in this regard has been the impact of loosening disability program eligibility restrictions for those with mental health problems (especially children), and for those suffering from AIDS/HIV or drug addiction and alcoholism. Disability program recipients clearly no longer resemble the original DI target population of older, disabled workers.

The third part of the volume includes a heterogeneous collection of short essays delving into the issues of disability program growth from the perspective of program officials, as well as policy analysts and experts. While the links between a number of these articles and the remainder of the book are at best tenuous given the political agendas of some contributors, together the essays in this third section of the book provide a broad 
overview of policy issues that should be examined in light of future reform initiatives. Perhaps the most interesting policy issue, raised repeatedly by contributors to this section, has to do with proposed restructuring of disability benefit programs to provide work incentives.

In conclusion, while the book is easily accessible to those without quantitative skills, it's subject matter is likely to be of particularly interest to a more limited audience, namely actors in the disability community. Furthermore, because the volume targets an American audience, those less familiar with U.S. social security system may wish to obtain background information before reading the text. The major strength of the book is its reliance on multiple data sources; quantitative analyses which are limited by the available data are supplemented with qualitative evidence to provide a more balanced overview of disability program growth trends. Comments provided at the end of chapters in the first and second sections offer useful and alternative insights to the material presented in those chapters. A weakness of the text is its failure to provide a comprehensive policy proposal that addresses issues of program growth; the third section of the book only hints at such reform initiatives in a disparate fashion.

SILVANA POZZEBON École des Hautes Études Commerciales, Montréal

\section{Fonction formation}

par Jacques SAYER, Paris : Éditions d'Organisation, 1998, 371 p., ISBN 2-70812153-7.

J'ai lu avec grand intérêt ce volume abordant la formation sous l'angle du praticien. Celui-ci- regroupe onze chapitres et fait un survol intéressant des aspects structurels, organisationnels, stratégiques, techniques et humains de la formation en entreprise. L'auteur touche la structure, la politique, la mobilisation, l'intégration, le diagnostic, le plan, la réalisation et l'évaluation de la formation. Il ajoute un chapitre sur les normes ISO 9001,9002 ou 9003.

Dans l'ensemble, la structure du livre est cohérente. Cependant, on n'aborde pas le processus d'apprentissage chez l'humain. De plus, le chapitre 8, "Comment analyser une demande et monter une formation efficace? " devrait se situer avant le chapitre 5 « Comment recenser les besoins de formation? ». L'analyse et la compréhension d'une demande de formation doit, selon moi, se réaliser dès le début du processus. Je m'interroge sur la pertinence du chapitre 11 sur la norme ISO, je n'ai pas bien senti le lien de ce chapitre avec le reste du volume. Si on voulait tirer un fil conducteur entre la formation et les exigences de la norme ISO, on devrait le faire avec plus d'insistance car ce chapitre est un peu succinct.

Finalement, au niveau académique, le fait de n'avoir aucune bibliographie laisse croire que ce livre est la vision ou l'opinion d'une seule personne, ce qui ne semble pas le cas à sa lecture. C'est donc un très bon livre pour les praticiens qui veulent se sensibiliser au processus de la formation en entreprise.

ROCH LAFLAMME Université Laval 